\title{
Complexities of regional and interregional interactions during the Formative Period in northern Peru: new perspectives from Ingatambo, Huancabamba Valley
}

\author{
Atsushi Yамамото ${ }^{1 *}$ \\ ${ }^{1}$ Faculty of Humanities and Social Sciences, Yamagata University, Kojiwakawa 1-4-12, Yamagata, Yamagata 990-8560, Japan
}

Received 2 March 2021; accepted 9 April 2021

\begin{abstract}
This article describes the changing regional and interregional entanglements in northern Peru during the Middle and Late Formative Periods from a diachronic perspective. Comparing the available archaeological data from major or 'core' ceremonial centers such as Kuntur Wasi and Pacopampa, and the contemporaneous center at Ingatambo, located in the northern 'frontier,' it seems reasonable to divide the diachronic process of interactions in northern Peru into three distinct phases to better understand its complexities. From this perspective, northern Peru around 1200 BC can be considered as an aggregate of local spheres (at the level of a valley or basin), with each of the local spheres pertaining to the emerging ceremonial centers. However, a major change seems to have occurred around $1000 \mathrm{BC}$, as regional and interregional interaction became more active in the northern highlands, and regional spheres seem to have expanded in number and geographic scale. Ceremonial centers such as Kuntur Wasi and Pacopampa formed regional-scale spheres beyond a geographically specific area. Around 800 $\mathrm{BC}$, radical socioeconomic changes occurred in the Central Andes, and northern Peru was integrated into a pan-regional network covering the whole of the Central Andes, which overlay the northern interaction spheres developed by important centers such as Kuntur Wasi and Pacopampa. In this context, it seems important to focus on the site of Ingatambo, which is located at a unique geopolitical point where multiple spheres overlap and interact with the two core centers of Kuntur Wasi and Pacopampa simultaneously. Ingatambo formed and maintained its own regional sphere independent of these two centers through its connection with the far north coast and tropical lowlands.
\end{abstract}

Key words: interaction, socioeconomic dynamics, diachronic perspective, Formative Period, Andes

\section{Introduction}

The Formative Period (3000-1 BC) in the Central Andes can be characterized as a time when socioeconomic development focused on ceremonial centers with large-scale public architecture (Figure 1). The activities conducted in these centers, including monumental construction projects and ritual activities, have been considered crucial to the early formation of Andean civilizations (Seki, 2014b; Burger et al., 2019). However, it is widely recognized that interregional interactions played an important role in socioeconomic development during this period; thus, several archaeologists have explored appropriate frameworks to understand this process better on a pan-regional scale (Yamamoto, 2013;

\footnotetext{
* Correspondence to: Atsushi Yamamoto, Faculty of Humanities and Social Sciences, Yamagata University, Kojiwakawa 1-4-12, Yamagata, Yamagata 990-8560, Japan.

E-mail: 1lamamoto@human.kj.yamagata-u.ac.jp

Published online 22 July 2021

in J-STAGE (www.jstage.jst.go.jp) DOI: 10.1537/ase.210409
}

Clasby, 2014, 2019; Matsumoto et al., 2018; Matsumoto, 2019).

The existence of interregional exchange beyond the area where daily living activities were conducted has been identified as occurring since the beginning of the Formative Period among the distinct ecological environments of the coast, highlands, and tropical lowlands (Burger, 1992; Church, 1996). However, recent studies indicate that the movement of people and goods became more active after the Middle Formative Period (1200-800 BC) (Yamamoto, 2010, 2013; Nesbitt, 2012). A pan-Andean exchange network covering the wide geographic area of the Central Andes was thought to have been established in the Late Formative Period ( 800 250 BC) (Burger, 1988, 1993, 2008, 2012).

These general diachronic changes in the Central Andes are also related to data from the contemporary northern highlands. To understand the regional nature of this process, it is important to focus on the two most important centersKuntur Wasi and Pacopampa - where large-scale archaeological projects are being conducted, and for which highresolution datasets are available (Table 1). Construction of 


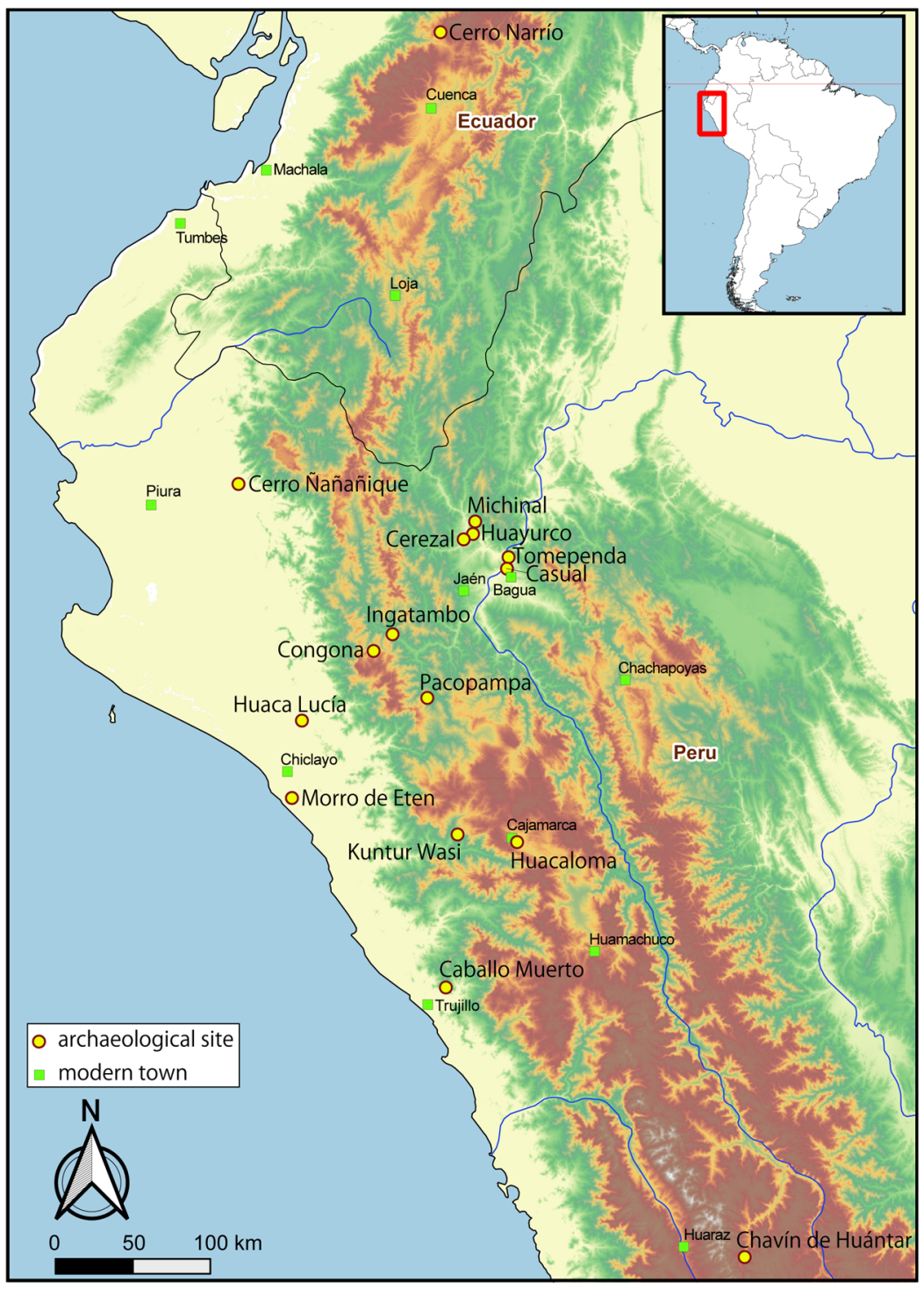

Figure 1. Location of Ingatambo and other key centers mentioned in text.

these two principal centers began around $1200 \mathrm{BC}$ at Pacopampa and $1000 \mathrm{BC}$ at Kuntur Wasi. It is evident that the major socioeconomic transformation took place in these centers around $800 \mathrm{BC}$, associated with radical changes in interregional interactions. However, it has also been pointed out that this process of socioeconomic transformation, including the emergence of a marked social hierarchy at each site, did not occur through a unidirectional process of coreperiphery or acculturation (Onuki, 1995; Inokuchi, 2010, 2014; Kato, 2014; Seki, 2014a; Seki et al., 2019). It is necessary to understand this process in northern Peru in relation to autonomous centers that interact with each other (Matsumoto et al., 2018).

In this paper, I deal with the complexities of the multiple levels of interactions from a diachronic perspective, focusing on northern Peru during the Middle and Late Formative Period. For this purpose, I will use data not only from Kuntur Wasi and Pacopampa but also from Ingatambo, a con- temporaneous center located in an area farther north that has been considered a 'periphery' or 'frontier.' Recent studies have pointed out that Ingatambo functioned as an important node of interaction between the north coast, highlands, and tropical lowlands and played a crucial role in the development of the societies in northern Peru (Yamamoto, 2010, 2013; Clasby, 2014, 2019). Simultaneously, this region is also considered a strategic place for exchange between the coast, highlands, and tropical lowlands, suggesting that societies in this region actively engaged in local, regional, and interregional interactions (Shady and Rosas, 1979; Shady, 2002; Yamamoto, 2010, 2013; Clasby, 2014, 2019; Olivera, 2014). Ingatambo is crucial because it is one of the largest ceremonial centers in the region and is located at an important point of interregional routes.

In Andean archaeology, two distinct chronological frameworks coexist in the archaeological literature. One is generally used in Peru and Japan, and is characterized by an evo- 
Table 1. Chronology of Ingatambo and other important regions (in upper case) and centers

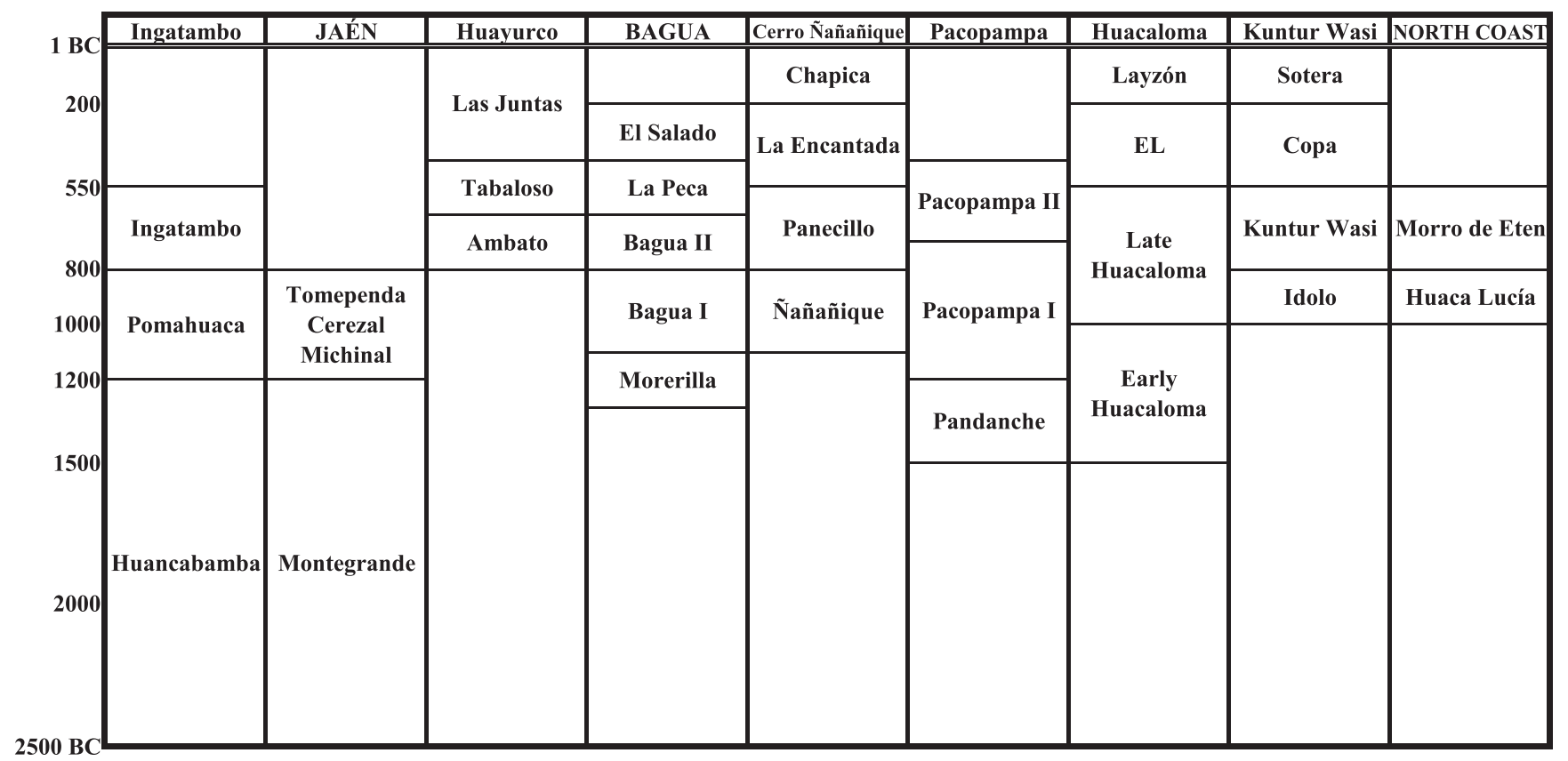

lutionary scheme in which the time period concerned in this paper is called as the 'Formative Period.' The other is used in the United States and was originally proposed by John H. Rowe to avoid the evolutionary implications for chronological terms (for detailed arguments about the chronological frameworks in Andean archaeology, see Ramón, 2005). These two frameworks are based on different theoretical implications and thus not fully compatible. Although I adopt the term 'Formative Period' partially because of the correspondence with the fine-grained chronology established by the Japanese team at Kuntur Wasi and Pacopampa, the Middle and Late Formative Period approximately coincide with the Initial Period and Early Horizon in the other framework.

As a geographic area, 'northern Peru' was once considered to be equivalent to the range stretching from the Piura to the Huarmey Valley (e.g. Bennett, 1939: 11). Subsequently, however, it has been more narrowly defined as the region from the Lambayeque to the Santa Valley, and the area north of the Lambayeque Valley is often referred to as the 'far north' (e.g. Willey, 1971: 87) and/or 'frontier' (e.g. Burger, 1992: 99). In this case, the Huancabamba Valley is located just between the north and the far north.

\section{The nature of regional and interregional interac- tions during the Andean Formative}

The Chavín phenomenon: two different spheres?

The social changes that occurred around $800 \mathrm{BC}$ were part of the radical socioeconomic changes known as the 'Chavín phenomenon,' closely linked to the development of interregional and pan-regional exchange networks, also known as the 'Chavín Interaction Sphere' (Burger, 1988, 1992, 1993, 2008, 2012). In this context, attempts have been made to interpret the interaction sphere in central and south- ern Peru and the relationship between Chavín de Huántar, the principal ceremonial center in the central highlands, and other ceremonial centers within the framework of coreperiphery relations or world systems theory (Burger and Matos, 2002; Matsumoto et al., 2018). However, the situation in northern Peru is considerably different from that in south-central Peru, suggesting that there may have been a unique exchange network centered on two principal centers, Kuntur Wasi and Pacopampa (Matsumoto et al., 2018). In addition, the archaeological data from Kuntur Wasi and $\mathrm{Pa}$ copampa demonstrate regional diversity in the formation process of public centers with monumental architecture and the emergence of social differentiation in the northern highlands (Seki, 2014a; Seki et al., 2019). Therefore, interregional exchange in northern Peru needs to be viewed from a diachronic perspective, considering the historicity of each center. Although this approach considers the ceremonial centers as nodes of interaction (Shady and Rosas, 1979; Burger, 1984; Church, 1996), it is important to evaluate the ways in which interaction spheres at different scales developed around these nodes by their coexistence, degree of overlap, and entanglement.

\section{Interregional interactions in northern Peru: focusing on Kuntur Wasi and Pacopampa}

\section{The Middle Formative Period}

During the Middle Formative Period, various activities were conducted in the ceremonial center in accordance with the growth of monumental architecture in scale, artistic elaboration, and labor investment for construction projects. This happened despite the relatively egalitarian character of the societies that successfully constructed and maintained these centers (Burger and Salazar, 2014; Seki, 2014a; Seki et al., 
2019). It is assumed that ceremonial centers became large as a result of repeated construction or renovation activities over a long period and that a small population could afford to carry out each construction event (Onuki, 1993; Kato and Seki, 1998; Burger, 2009; Nesbitt, 2012). There are also significant changes in material culture, including the use of animal representations, such as humans, felines, and snakes on the pottery and wall decorations of these centers (Burger, 1992).

A high degree of similarity in material culture can be observed within a particular regional spread. On the north coast, this is the case for the pottery style or archaeological culture known as Cupisnique (Larco, 1941; Elera, 1993); however, recent research has shown that Cupisnique ought not to be thought of as a unified cultural entity. Instead, because of its regional and temporal diversity, it is best conceived of as a diverse social field, which is defined by different patterns of interaction that change over time (Nesbitt, 2012). It has been suggested that interregional exchanges existed between the coast, highlands, and tropical lowlands, although these exchanges seem to have been sporadic events because only a few objects that indicate long distances have been recognized thus far.

Kuntur Wasi emerged as a ceremonial center of regional importance in the Idolo phase (950-800 BC) in its site chronology. People surrounding the nearby center of Cerro Blanco probably moved to Kuntur Wasi, constructed at least four small platforms and plazas, and maintained the center for a few centuries through repeated renovations (Inokuchi, 2010, 2014; Onuki and Inokuchi, 2011; Kato, 2014). The ceramic style of the Idolo phase shows similarities to neighboring centers such as Cerro Blanco and Huacaloma, Pacopampa in the northern highlands, and Cupisnique on the north coast (Inokuchi, 2010, 2014)

The presence of warm-water seashells from the far north of Peru and southern Ecuador, cinnabar from the southern Peruvian highlands, and Bolivian sodalite seems to suggest interregional trade. However, because of the limited quantity of such prestigious items obtained through interregional trade, it seems reasonable to consider Kuntur Wasi to be a center of primarily regional importance (Kato, 2014).

Conversely, during the Pacopampa I phase (1200-700 BC), a stepped platform and several smaller platforms and patios were constructed early on (Seki, 2014a). Around 1000 $\mathrm{BC}$, major architectural changes occurred, including the construction of multiple platforms, a sunken square plaza, and circular buildings covering the previous architecture. In addition, the main buildings were constructed, including five enclosures in which burning rituals seem to have been performed. Ceramic styles from this phase show a high degree of similarity to those of Huacaloma and Kuntur Wasi, but little evidence that suggests long-distance contact has been recovered (Seki, 2014a; Nakagawa et al., 2016, 2019; Seki et al., 2019). Notably, the use of camelids, which are supposedly used as pack animals in the Andes and are closely associated with interregional exchanges, has been reported from this phase although examples are relatively scarce (Uzawa et al., 2021), suggesting that opportunities for interregional interaction were only sporadic. Reports of camelids in northern Peru during this period are limited to a few sites, such as
Huacaloma (Shimada, 1982) and Huaca Lucia on the north coast (Shimada et al., 1982). In this context, it seems important to note that camelid remains are found from earlier occupations on the coast such as the Templo de las Llamas in the Viru Valley (e.g. Strong and Evans, 1952) and Puémape in the Jequetepeque Valley (Elera, 1998). The introduction of camelid herding in northern Peru needs further evaluations with better-quality data sets.

Changes similar to those in Pacopampa have also been identified at Huacaloma in the Cajamarca Basin. At Huacaloma, architectural changes occurred around $1000 \mathrm{BC}$, with the construction of platform structures associated with ceramic styles related to Kuntur Wasi and Pacopampa. However, evidence of interregional exchange remains scarce (Seki, 2014a).

\section{The Late Formative Period}

In the Late Formative Period, significant socioeconomic changes occurred in northern Peru. These include the growth in the size and complexity of ceremonial centers, changes in plant and animal use, technological innovations in metalworking and monumental construction, expansion and intensification of interregional interactions, and the emergence of social hierarchies within each center (Burger, 1992; Seki, 2014b; Burger et al., 2019).

At Kuntur Wasi, during the Kuntur Wasi phase (800-550 $\mathrm{BC}$ ), the ceremonial architecture was constructed symmetrically with a new axis on top of the structures of the previous phase, as if intending its rejection and that of several implications associated with it (Inokuchi, 2010, 2014; Onuki and Inokuchi, 2011; Kato, 2014). The new monumental complex at Kuntur Wasi consisted of many rectangular platforms, multiple sunken square plazas, a sunken circular plaza, and many drainage canals. In addition, elite burials with gold objects and cinnabar were found in the main platform, as well as many artifacts indicative of long-distance exchange, such as warm-water seashells, Bolivian sodalite, and obsidian from the southern highlands of Peru and Ecuador (Onuki, 1995; Burger and Glascock, 2009; Onuki and Inokuchi, 2011; Kato, 2014). The variation in pottery style also increased, showing similarities with the centers in the northern highlands and north coast, as represented by the Cupisnique style (Inokuchi, 2010, 2014). The use of camelids also began in this phase (Uzawa, 2008, 2019). Researchers consider that these socioeconomic changes in Kuntur Wasi occurred through interactions with the centers of the Cupisnique culture on the north coast, rather than as a result of local continuity from the Idlo phase (Inokuchi, 2010, 2014; Kato, 2014; Seki, 2014a). Kuntur Wasi transformed itself from a local center to one with influence over a much broader geographic area, including the northern highlands and north coast (Kato, 2014; Inokuchi and Druc, 2019). It has also been hypothesized that the intensification of interregional interactions, including long-distance exchange and craft production, played an important role in the transformation of Kuntur Wasi (Seki, 2014a) and that leaders manipulated power by controlling these interactions and rejecting the ideologies of the previous phase (Seki, 2014a; Seki et al., 2019).

Conversely, at Pacopampa, the overall plan of the archi- 
tecture was basically the same as that of the previous phase. However, there were some architectural changes during the Pacopampa II phase (700-400 BC), as represented by the construction of a new patio and more control over access to the central structure. In addition, special tombs associated with gold objects, marine shells, cinnabar, and azulite have been identified (Seki, 2014a; Seki et al., 2019). The pottery style shows a certain relationship with Cupisnique rather than the previous phase and some similarities with Kuntur Wasi, although it also shows unique local characteristics different from Kuntur Wasi (Nakagawa et al., 2016, 2019; Seki et al., 2019). Furthermore, camelids had become more prevalent (Uzawa et al., 2021) and isotopic evidence suggests that camelid husbandry began during this phase (Takigami et al., 2020). Importantly, recent data from Pacopampa suggest that the increased use of camelids might not necessarily reflect an intensification of interregional interaction and may instead imply their increased importance in domestic and ritual use at Pacopampa (Uzawa et al., 2021). These new data might also suggest that Pacopampa was involved in the interaction with the centers on the north coast and north highlands utilizing its own camelids, which is also supported by the fact that the number of objects related to long-distance trade was scarcer than in Kuntur Wasi (Seki, 2014a). This working hypothesis agrees well with Seki's view that the leaders at Pacopampa manipulated their power by controlling access to copper smelting and monumental construction projects, as well as through long-distance exchange (Seki, 2014a). In any case, the role of camelids in northern Peru during this period remains to be evaluated in the future using new data sets.

\section{Interregional interactions and socioeconomic transformations in the Peruvian north highlands}

Kuntur Wasi and Pacopampa show their own unique trajectories of socioeconomic development. However, it is also clear that both of these centers in the northern highlands had been interacting with each other since the Middle Formative Period. Nevertheless, Pacopampa and Kuntur Wasi also formed distinct regional interaction spheres independently, even while overlapping in the northern highlands. The data suggest that Pacopampa was related to the centers further north and east, revolving around the northern part of the northern highlands covering the tropical lowlands. Kuntur Wasi had a strong relationship with the centers located in the southern part of the northern highlands such as Cajamarca Basin and the Cupisnique culture on the north coast.

Kuntur Wasi and Pacopampa also simultaneously experienced radical socioeconomic changes around $800 \mathrm{BC}$, and they then began to share several artifacts and art styles that originated not only in northern Peru but also in other regions. However, upon closer examination, there are also important differences between these two centers, such as pottery style, specific types of architecture, and religious iconography. These data suggest that each center functioned as an independent political and religious unit and interacted with peer polities (Renfrew and Cherry, 1986; Burger, 1993).

\section{Ingatambo: ceremonial center in the northern frontier}

The archaeological site of Ingatambo and its geographic setting

Ingatambo is located on a natural plateau along the southern margin of the Huancabamba Valley at an elevation of 1066 masl. It is composed of a large architectural complex consisting of platforms and plaza-like open spaces (Figure 2).

Based on our investigation at Ingatambo, a three-phase site chronology in the Formative Period was established (Yamamoto, 2010, 2013). Of these, the latter two phases are particularly relevant to the theme of this paper (Figure 3): the Pomahuaca phase (Middle Formative Period) and the Ingatambo phase (Late Formative Period).

Notably, the Huancabamba Valley is an important corridor of both north-south and east-west exchange through the Andes. Ingatambo, with its location at the center of this geographic nexus, was in a strategic position to take advantage of emerging socioeconomic/political networks, and the growth of the site reflects its larger role within early interaction spheres.

\section{The Pomahuaca phase (1200-800 BC: Middle Formative Period)}

The ceremonial architecture at Ingatambo was built through several constructions, which might be regarded as renovation because the structures of the previous phase (Huancabamba phase: 2500-1200 BC) were completely covered, and the size of the architecture increased to take on

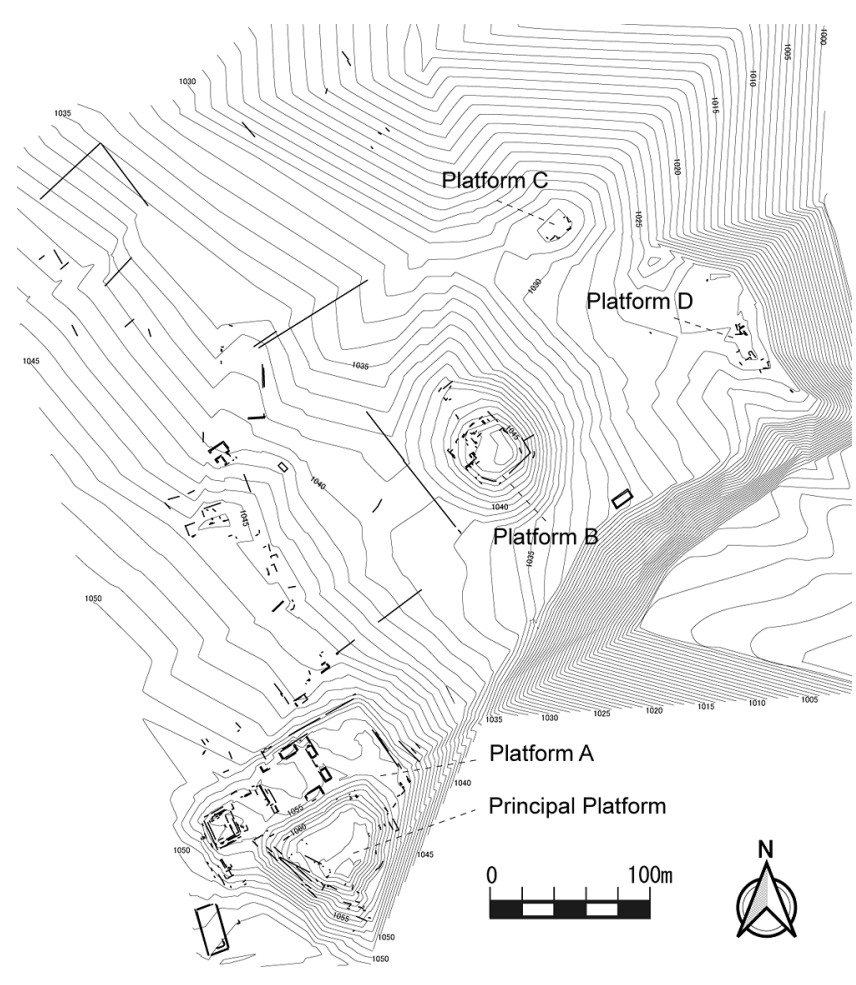

Figure 2. Plan of Ingatambo. 


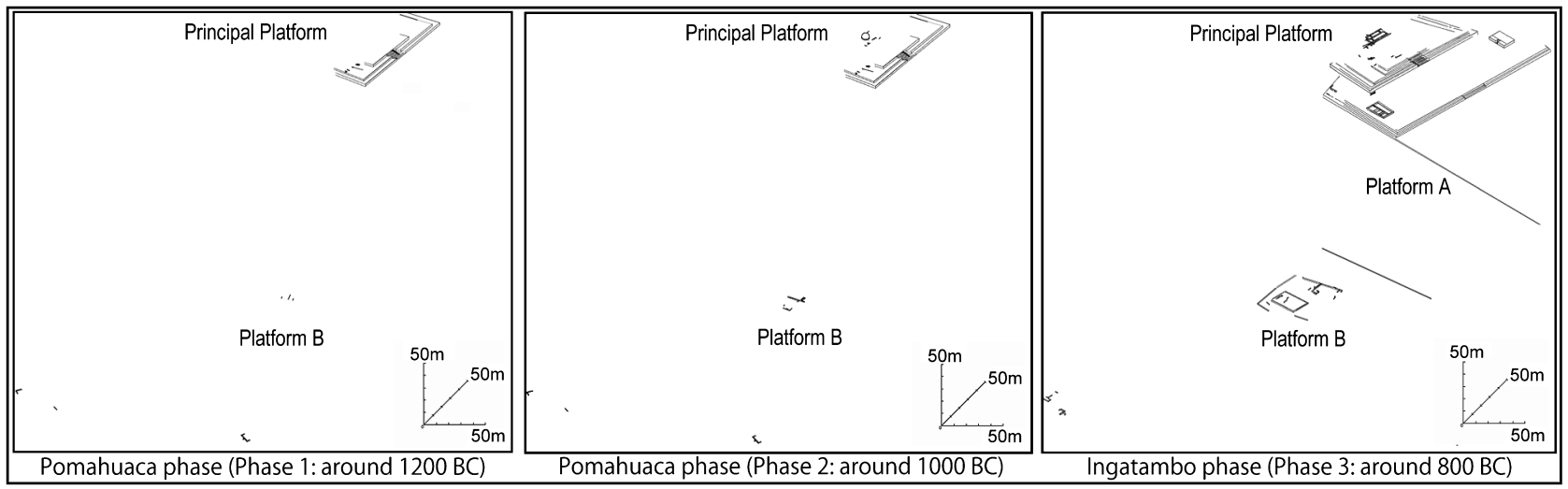

Figure 3. Architectural sequence of Ingatambo.

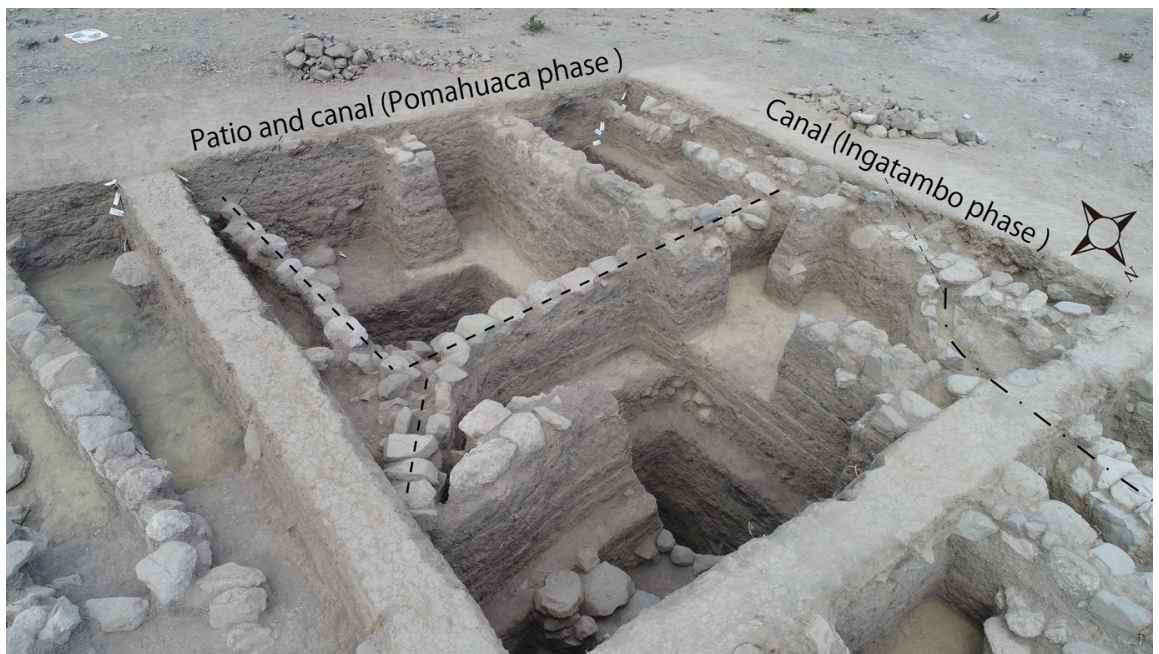

Figure 4. Structures on the top of the principal platform showing the patio and canal.

a monumental character. Architecturally, Ingatambo shows several important similarities to contemporary centers such as Cerro Nañañique (Guffroy, 1989, 1994) and Tomependa (Olivera, 1998). This is represented by constructions of multiple independent platforms and other architectural techniques such as the use of small irregular stones with mud mortar and yellow plaster on the wall surfaces, which contrast strongly with the large centers of the northern highlands_-Pacopampa and Kuntur Wasi.

However, in the later part of this phase rectangular and circular enclosures that were well elaborated and finished with plaster, and a rectangular patio with a canal at the corner, were constructed on top of the principal platform and with these changes the public architecture of Ingatambo shows close similarities with Pacopampa (Seki, 2014a; Seki et al., 2019) (Figure 4).

Ceramics at Ingatambo show general stylistic similarities with contemporary sites in neighboring regions (Figure 5), such as Cerro Nañañique (Guffroy, 1989, 1994; Kaulicke, 1998), Cerezal, Michinal, and Tomependa (Miasta, 1979; Olivera, 1998), and Pacopampa (Nakagawa et al., 2016, 2019). Stylistic links are especially strong in the ceramic assemblage from Cerro Nañañique in terms of both decorative techniques and the abundance of short-necked jars.

However, ceramic assemblages at Ingatambo do not bear much resemblance to those of Kuntur Wasi (Onuki, 1995; Inokuchi, 2010, 2014; Onuki and Inokuchi, 2011) and Huaca Lucia (Shimada et al., 1982). In terms of the other evidence of interregional interaction at Ingatambo, apart from the architecture and ceramic styles, there is an extensive presence of marine shells.

Ingatambo underwent significant changes that reflected its involvement in interactions with neighboring areas as an important node of interaction. This idea might be supported by the introduction of camelids during this phase, although, as mentioned earlier, we should be cautious about assuming a direct link with intensified interregional interactions (Uzawa et al., 2021). However, it is worth considering the possibility that as a result of the reorientation of exchange routes, caravans began to use the higher-elevation routes along the Huancabamba Valley (Yamamoto, 2013).

The Ingatambo phase (800-550 BC: Late Formative Period) The architecture at Ingatambo significantly increased in 


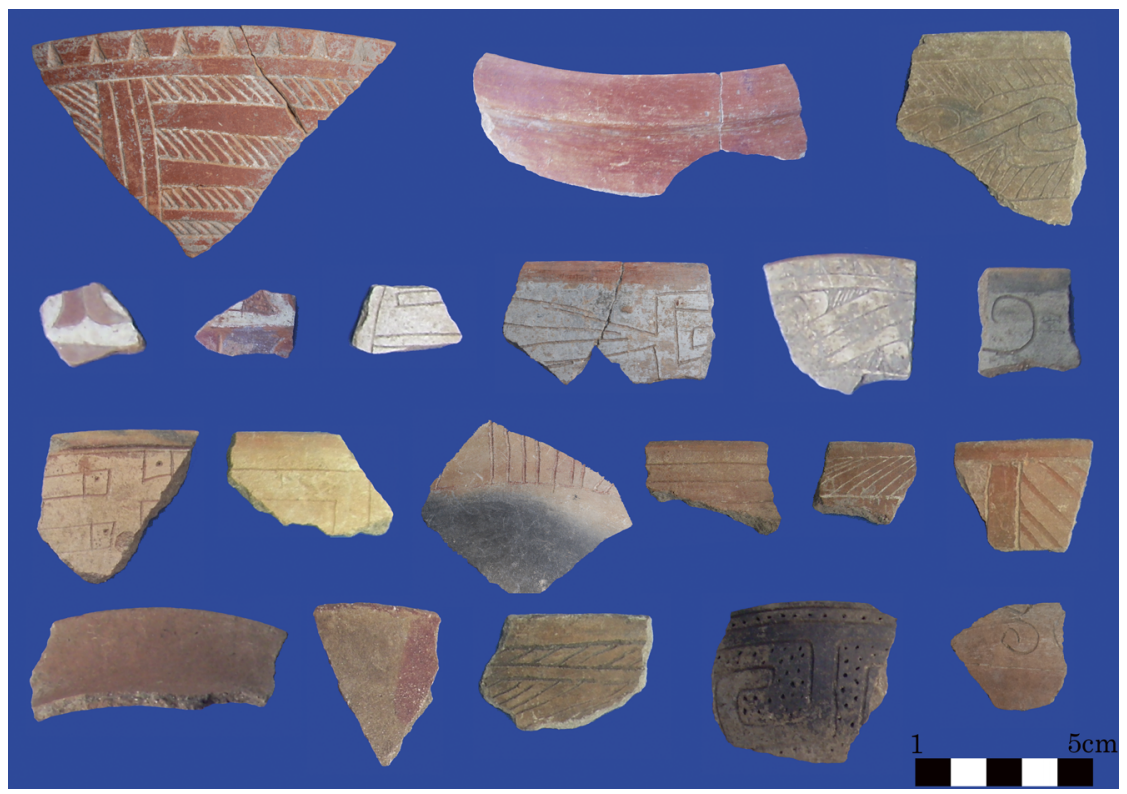

Figure 5. Ceramic assemblage, Pomahuaca phase.

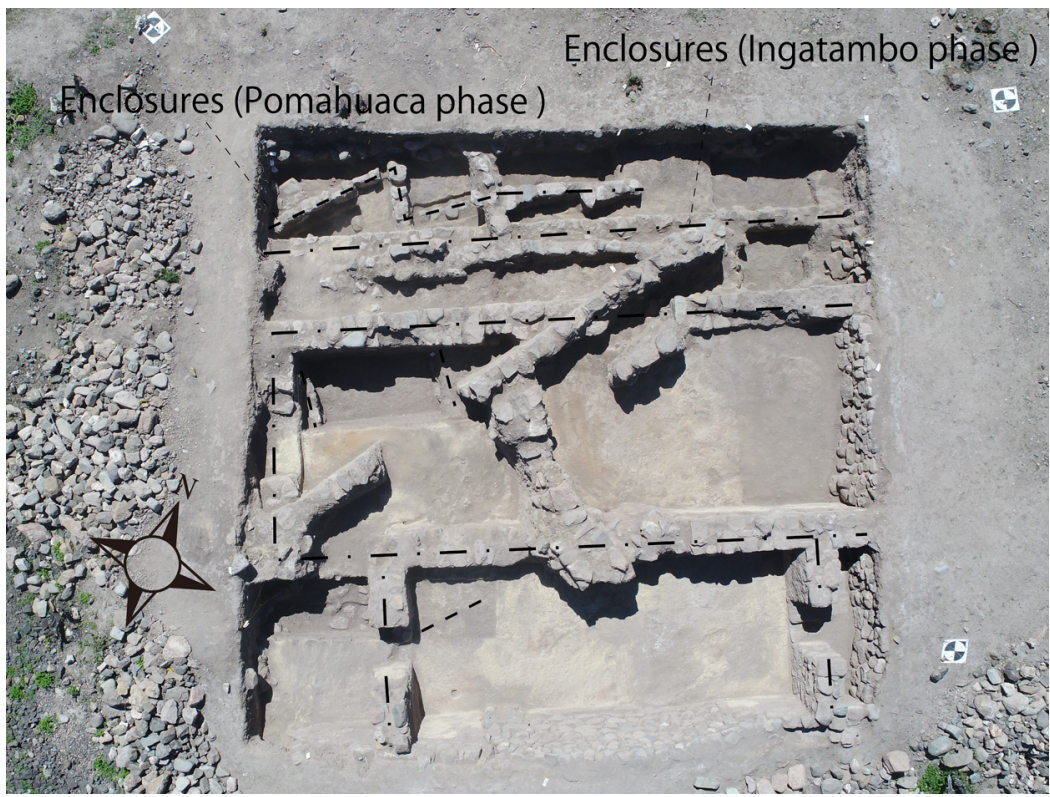

Figure 6. Enclosures on the top of the principal platform.

size and complexity through renovation activities (Figure 6). Large, more complex enclosures with restricted access, low rectangular platforms, and a canal were built in the upper part of the principal platform. This principal platform and other associated architectural features show a certain similarity with Pacopampa in terms of layout and architectural arrangement, especially the primary area of the main platform at Pacopampa. Ingatambo maintained some similarity with Cerro Ñañañique (Guffroy, 1989, 1994) and Huayurco (Clasby, 2014, 2019) in terms of architectural technique, as was the case in the previous phase. However, Ingatambo also began to utilize quarried rectangular stone blocks simi- lar to those at Pacopampa and Kuntur Wasi, although this new technique was applied only to one important part of the monumental architecture, a retaining wall of the principal platform.

The changes in ceramic style during this phase also accord with this architectural change, and distinctly greater stylistic variations were identified (Figure 7). Some pieces show similarities with Cerro Ñañañique (Guffroy, 1989, 1994; Kaulicke, 1998), Huayurco (Clasby, 2014, 2019), and Pacopampa (Nakagawa et al., 2016, 2019) as in the previous phase. Others show similarities with Kuntur Wasi (Onuki, 1995; Inokuchi, 2010, 2014; Onuki and Inokuchi, 2011), 


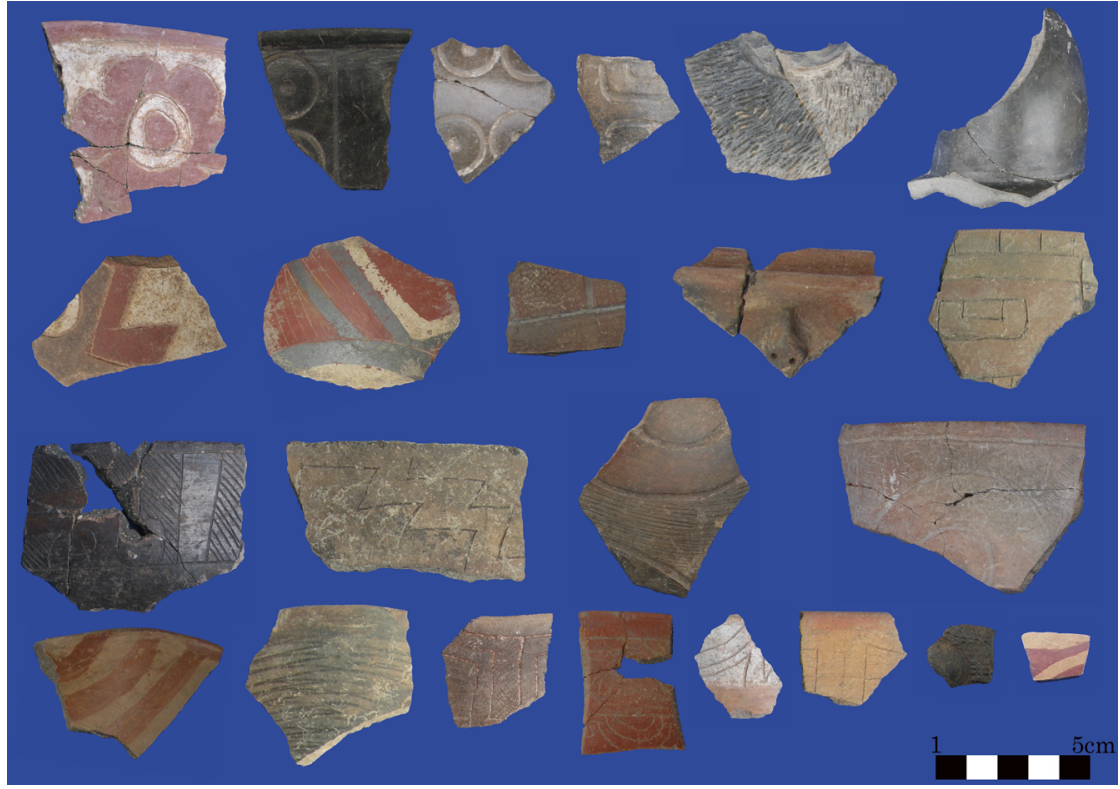

Figure 7. Ceramic assemblage, Ingatambo phase.

Huacaloma (Terada and Onuki, 1982, 1985), and Morro de Eten (Elera, 1986).

Evidence of long-distance transportation indicates that interregional interaction centered on Ingatambo was further intensified and expanded, as can be seen in the pottery, warm-water marine shells, and obsidian artifacts from Quispisisa in south-central Peru, despite its closer geographic proximity to obsidian sources in Ecuador.

While taking due note of the possible implications arising from the new data of Pacopampa, this change in Ingatambo seems to have been related to the intensification of camelid use for transportation during this phase because of its location as a crossroads for several important long-distance transportation routes. Although this change first began in the Pomahuaca phase, it could have been a result of Ingatambo's involvement in the wider network of pan-regional interactions (Yamamoto, 2013).

\section{Ingatambo as a site in the northern frontier of the Ande- an Formative Period}

The archaeological data from Ingatambo reflect the complex entanglement of multiple levels of interaction through a long-term diachronic process. Ingatambo was linked to larger ceremonial centers in the northern highlands, such as Kuntur Wasi and Pacopampa, but is simultaneously rooted in regional processes and sociocultural developments, according to the activities and strategies of each center. These centers played various roles in different kinds of overlapping local, regional, and interregional networks of interaction within the northern highlands.

It might be useful to consider Ingatambo as a site in the northern frontier of the Formative Andes. As discussed by Van Gijseghen (2006), frontier should not be considered as a passive receptor of outside influence. In this sense, the frontier does not necessarily presuppose a single institutionalized polity and should be regarded as an active area of cul- tural contact resulting in ethnogenesis, creolization, syncretism, etc. (Parker, 2006; Feuer, 2016; Green and Costion, 2018), as a result of the complex entanglements of multiple spheres of interaction.

\section{Complexities of regional and interregional interac- tions and socioeconomic dynamics during the Formative Period in northern Peru}

Three important moments in the changing interregional interactions

The history of Ingatambo as a ceremonial center reflects important changes in socioeconomic organizations and regional/interregional interactions in northern Peru. In the Middle Formative Period, the ceremonial center became larger and more complex, and interregional interaction began to be activated through exchange routes. In the Late Formative Period, Ingatambo intensively interacted with Pacopampa and Kuntur Wasi as a part of regional and interregional networks. In this context, a diachronic perspective seems productive for considering changing interactions in northern Peru in relation to the socioeconomic transformation of the region.

\section{Phase 1: 1200-1000 BC}

Ingatambo became the principal center of the Huancabamba Valley (Yamamoto, 2007) and transformed from a local center to an important center, like a 'gateway community' (Hirth, 1978) and/or 'transit community' (Bandy, 2005). It served as a geopolitically important site for helping to facilitate the reliable interregional flow of goods, taking advantage of its geographic and strategic location in the interregional socioeconomic/political networks (Yamamoto, 2013).

Ingatambo's exchange networks demonstrate their diversity at both the regional and interregional levels. The archi- 
tecture and pottery styles show a high degree of similarity with those of Cerro Nañañique and Tomependa, while the presence of marine shells suggests a relationship with the societies along the coast, especially in the far north of Peru and southern Ecuador. Ingatambo probably participated in the network of marine shell transportation from north to south. The presence of camelids suggests a tie with Pacopampa and Huaca Lucia, but overall, the relationship with Pacopampa and Kuntur Wasi is less apparent than that with Cerro Ñañañique.

Interactions in northern Peru gradually increased. However, in Ingatambo, the relationship with Pacopampa seems to have been limited. In other words, Pacopampa and Ingatambo functioned as autonomous centers in the regional sphere of northern Peru. These two locations were centered on their own connections to other regions, which might be regarded as their local interaction spheres. Ingatambo's interaction sphere overlapped slightly with those of Pacopampa and Huaca Lucia and was mainly connected to Cerro Ñañañique and Tomependa.

Presumably, each center functioned as a sort of peer polity, and their relationships would not have been as dominant/ subordinates or core/peripheries.

\section{Phase 2: 1000-800 BC}

The architecture of Ingatambo changed to feature rectangular enclosures, a patio, and a canal, similar to the architecture of Pacopampa. These new structures were likely the loci of ritual activities and thus suggest that Ingatambo had close ideological connections to Pacopampa (Seki, 2014a; Seki et al., 2019). However, other materials, such as pottery and marine shells, indicate a close connection with the far north coast and tropical lowlands rather than the northern highlands.

During this phase, the regional interaction sphere pertaining to Ingatambo expanded more to the south and strengthened its relationship with Pacopampa, the principal center of the northern highlands, accepting its influence, especially in religious ideology.

\section{Phase 3: 800-500 BC}

Around $800 \mathrm{BC}$, Ingatambo, like other centers in northern Peru, underwent radical social changes. The architectural character of the main structures of the platform demonstrates a closer relationship with Pacopampa, and the influence of religious ideology from Pacopampa continued to increase from the former phase.

In terms of pottery style, while utilitarian vessels show strong continuities, the overall variations became much wider, as represented by the appearance of new ceramic forms and decorative techniques, suggesting a stronger relationship with major centers such as Pacopampa, Kuntur Wasi, and Morro de Eten. In addition, the stylistic similarities in the pottery of Ingatambo and Pacopampa (Nakagawa et al., 2016, 2019) or Congona in the northern highlands (Watanabe, 2008) suggest that there was an interaction sphere centered on Pacopampa in the northern part of the northern highlands and that Ingatambo became involved in it.

Other artifacts seem to reflect these changes. For example, it seems reasonable to assume that the gold artifacts looted at
Ingatambo belong to this phase; thus, Ingatambo may have undergone changes in social organization similar to those at Kuntur Wasi and Pacopampa. Further, obsidian from the southern highlands of Peru clearly indicates that Ingatambo was involved in the pan-regional network in which both Kuntur Wasi and Pacopampa participated. One can assume that the pan-regional network that overlapped Ingatambo's interaction sphere expanded in the wide geographic area of the central Andes and incorporated the societies located further north and on the eastern slopes of the Andes. The socioeconomic changes that occurred at Huayurco support this assumption (Clasby, 2014, 2019).

These data seem to imply that the overlapping regional and interregional networks of each center in northern Peru expanded and intensified to form a broader interregional interaction sphere.

\section{Conclusion}

Interactions in northern Peru changed significantly over time, with three distinct phases. Ingatambo became increasingly involved in local, regional, and interregional interaction networks and played a significant role in facilitating the maintenance of these networks (Yamamoto, 2010, 2013).

The northern interaction sphere in the Middle Formative Period around $1200 \mathrm{BC}$ (Phase 1) could be understood as the overlapping networks of the centers of autonomous polities, which basically had different local spheres.

However, a major change seems to have occurred around $1000 \mathrm{BC}$ (Phase 2), as the regional and interregional interactions became more active in the northern highlands. Small local networks sustained by modest-scale local centers likely expanded, intensified, and overlapped to form regional spheres that covered a wider geographic area. Phase 2 was characterized by diversity in material culture, reflecting variations in these regional spheres. For example, Kuntur Wasi displays more intensive interaction with the northern highlands and north coast, while Pacopampa may have focused its interactions on the northern highlands and tropical lowlands. In addition, these spheres partially overlapped with those of the Cupisnique culture on the north coast, as shown by the data of Kuntur Wasi. In this context, Ingatambo seems to have developed differently from these centers, and one can assume that this was due to its position as a gateway community and had a close relationship with the far north coast and tropical lowlands rather than the northern highlands.

In the case of the Late Formative Period around $800 \mathrm{BC}$ (Phase 3), northern Peru can be thought of as an area where the pan-Andean interregional sphere, sometimes referred to as the Chavín Interaction Sphere, overlaid the regional and interregional interaction sphere that continued from Phase 2.

Ingatambo was integrated into the pan-regional sphere, possibly through its relationship with Kuntur Wasi and Pacopampa. It seems reasonable to say that Kuntur Wasi and Pacopampa maintained different local spheres within the northern interaction sphere. Ingatambo was formed as a ceremonial center of regional importance in relation to the two centers, in addition to having its own connections with the far north coast and tropical lowlands. Consequently, In- 
gatambo demonstrates a mosaic of cultural elements. It can therefore reasonably be presumed that Ingatambo was also an autonomous political unit or one of the autonomous units strategically located within relations with Kuntur Wasi and Pacopampa and that it developed within that sphere.

Interactions in the Central Andes around $800 \mathrm{BC}$ have gradually become clearer through recent research. However, the details of interactions during the Middle Formative Period are still unclear and require further research, especially on the north coast.

\section{Acknowledgments}

I am deeply grateful to the two journal reviewers for their useful comments. I would also like to express my deepest appreciation to Yuichi Matsumoto for his insightful comments and suggestions. Research for the investigations at Ingatambo was supported by Grant-in-Aid for JSPS Research Fellow, Japan 19-186 and 21-490, Grant-in-Aid for Young Scientists (A), Japan 26704011 and 17H04778, and Grant-in-Aid for Scientific Research on Innovative Areas $19 \mathrm{H} 05732$.

\section{References}

Bandy M. (2005) Trade and social power in the southern Titicaca Basin Formative. In: Vaughn K., Ogburn D., and Conlee K. (eds.), Foundations of Power in the Prehispanic Andes. American Anthropological Association, Washington, DC, pp. 91111.

Bennett W. (1939) Archaeology of the north coast of Peru: An account of exploration and excavation in Viru and Lambayeque Valleys. Anthropological Papers of the American Museum of Natural History, Vol. 37, part 1. American Museum of Natural History, New York.

Burger R. (1984) Archaeological areas and prehistoric frontiers: the case of Formative Peru and Ecuador. In: Browman D., Burger R., and Rivera M. (eds.), Social and Economic Organization in the Prehispanic Andes. BAR International Series 194. British Archaeological Reports, Oxford, pp. 33-71.

Burger R. (1988) Unity and heterogeneity within the Chavín Horizon. In: Keatinge R. (ed.), Peruvian Prehistory. Cambridge University Press, Cambridge, pp. 99-144.

Burger R. (1992) Chavín and the Origins of Andean Civilization. Thames \& Hudson, New York.

Burger R. (1993) The Chavín Horizon: stylistic chimera or socioeconomic metamorphosis? In: Rice D. (ed.), Latin American Horizons. Dumbarton Oaks, Washington DC, pp. 41-82.

Burger R. (2008) Chavín de Huántar and its sphere of influence. In: Silverman H. and Isbell W. (eds.), Handbook of South American Archaeology. Springer, New York, pp. 681-703.

Burger R. (2009) Los fundamentos sociales de la arquitectura monumental del Periodo Inicial en el valle de Lurín. In: Burger R. and Makowski K. (eds.), Arqueología del Periodo Formativo en la Cuenca Baja de Lurín, Vol. 1. Fondo Editorial, Pontificia Universidad Católica del Peru, Lima, pp. 17-36.

Burger R. (2012) Central Andean language expansion and the Chavín sphere of interaction. In: Heggarty P. and BeresfordJones D. (eds.), Archaeology and Language in the Andes. Oxford University Press, Oxford, pp. 135-161.

Burger R. and Glascock M. (2009) Intercambio prehistórico de obsidiana a larga distancia en el Norte Peruano. Revista del Museo de Arqueología, Antropología e Historia, 11: 17-50.

Burger R. and Matos R. (2002) Atalla: a center on the periphery of Chavín Horizon. Latin American Antiquity, 13: 153-177.

Burger R. and Salazar L. (2014) ¿Centro de qué? Los sitios con arquitectura pública de la cultura Manchay. In: Seki Y. (ed.), El centro Ceremonial Andino: Nuevas perspectivas para los Períodos Arcaico y Formativo. Senri Ethnological Studies 89, National Museum of Ethnology, Osaka, pp. 291-313.

Burger R., Salazar L., and Seki Y. (eds.) (2019) Perspectives on Early Andean Civilization in Peru: Interaction, Authority, and Socioeconomic Organization During the First and Second Millennia BC. Yale University Press, New Haven, CT.

Church W. (1996) Prehistoric Cultural Development and Interregional Interaction in the Tropical Montane Forests of Peru. $\mathrm{PhD}$ dissertation, Yale University, New Haven, CT.

Clasby R. (2014) Exploring Long Term Cultural Developments and Interregional Interaction in the Eastern Slopes of the Andes: A Case Study from the site of Huayurco, Jaén Region, Peru. PhD Dissertation, Yale University, New Haven, CT.

Clasby R. (2019) Diachronic changes in sociopolitical developments and interregional interaction in the Early Horizon Western Montane Forest. In: Burger R., Salazar L., and Seki Y. (eds.), Perspectives on Early Andean Civilization in Peru: Interaction, Authority, and Socioeconomic Organization During the First and Second Millennia BC. Yale University Press, New Haven, CT, pp. 149-171.

Elera C. (1986) Investigaciones sobre patrones funerarios en el sitio formativo del Morro de Eten, valle de Lambayeque, costa norte del Perú. Memoria de Bachiller. Pontificia Universidad Católica del Perú, Lima.

Elera C. (1993) El complejo cultural Cupisnique: Antecedentes y desarrollo de su ideología religiosa. In: Millones L. and Onuki Y. (eds.), El Mundo Ceremonial Andino. Senri Ethnological Series, National Museum of Ethnology, Osaka, pp. 229-257.

Elera C. (1998) The Puémape Site and the Cupisnique Culture: A Case Study on the Origins and Development of Complex Society in the Central Andes, Peru. PhD dissertation, University of Calgary, Alberta. https://prism.ucalgary.ca/handle/1880/ 26224

Feuer B. (2016) Boundaries, Borders and Frontiers in Archaeology: A Study of Spatial Relationships. McFarland \& Co., Jefferson, NC.

Green U. and Costion K. (2018) Modeling Cross-cultural Interaction in Ancient Borderlands. University Press of Florida, Gainesville.

Guffroy J. (1989) Un centro ceremonial formativo en el Alto Piura. Bulletin de l'Institut Français d'Etudes Andines, 18: 161-207.

Guffroy J. (1994) Cerro Ñañañique: Un établissement monumental de la période formative, en limite de désert (Haut Piura, Pérou). Orstom Éditions, Paris.

Hirth K. (1978) Interregional trade and the formation of prehistoric gateway communities. American Antiquity, 43: 35-45.

Inokuchi K. (2010) La arquitectura de Kuntur Wasi: Secuencia constructiva y cronología de un centro ceremonial del Periodo Formativo. Boletín de Arqueología PUCP, 12: 219-247.

Inokuchi K. (2014) Cronología del Período Formativo de la sierra norte del Perú: Una consideración desde el punto de vista de la cronología local de Kuntur Wasi. In: Seki Y. (ed.), El centro Ceremonial Andino: Nuevas perspectivas para los Períodos Arcaico y Formativo. Senri Ethnological Studies 89, National Museum of Ethnology, Osaka, pp. 123-158.

Inokuchi K. and Druc I. (2019) Socioeconomic transformation at the ceremonial center of Kuntur Wasi: raw materials, craft production, and leadership. In: Burger R., Salazar L., and Seki Y. (eds.), Perspectives on Early Andean Civilization in Peru: Interaction, Authority, and Socioeconomic Organization During the First and Second Millennia BC. Yale University Press, New Haven, CT, pp. 83-95.

Kato Y. (2014) Kuntur Wasi: Un centro ceremonial del Período Formativo Tardío. In: Seki Y. (ed.), El centro Ceremonial Andino: Nuevas perspectivas para los Períodos Arcaico y Formativo. Senri Ethnological Studies 89, National Museum of Ethnology, Osaka, pp. 159-174.

Kato Y. and Seki Y. (eds.) (1998) Bunmei no Sozoryoku. Kadokawa 
shoten, Tokyo.

Kaulicke P. (1998) El Periodo Formativo de Piura. Boletín de Arqueología PUCP, 2: 19-36.

Larco R. (1941) Los Cupisniques: Trabajo presentado al Congeso Internacional de Americanistas de Lima XXVII Sesion. Casa Editora 'La Crónica' y 'Variedades' SA, Lima.

Matsumoto Y. (2019) South of Chavín: Initial Period and Early Horizon interregional intersections between the central highlands and south coast. In: Burger R., Salazar L., and Seki Y. (eds.), Perspectives on Early Andean Civilization in Peru: Interaction, Authority, and Socioeconomic Organization During the First and Second Millennia BC. Yale University Press, New Haven, CT, pp. 173-188.

Matsumoto Y., Nesbitt J., Glascock M., Cavero Y., and Burger R. (2018) Interregional obsidian exchange during the Late Initial Period and Early Horizon: new perspectives from Campanayuq Rumi, Peru. Latin American Antiquity, 29: 44-63.

Miasta J. (1979) El Alto Amazonas, Arqueología de Jaén y San Ignacio, Perú. Universidad Nacional Mayor de San Marcos, Dirección de Proyección Social, Seminario de Historia Rural Andina, Lima.

Nakagawa N., Seki Y., and Morales D. (2016) Repaired pottery and unrepaired pottery: the case of Pacopampa and Capilla in Formative Period. América Antigua, 19: 63-75 (in Japanese with English title).

Nakagawa N., Seki Y., Villanueva J., Ordoñez M., Aleman D., and Morales D. (2019) El proceso del Complejo Arqueológico Pacopampa. Actas V Congreso Nacional de Arqueología, Vol. 1. Ministerio de Cultura, Perú, pp. 199-209.

Nesbitt J. (2012) Excavations at Caballo Muerto: An Investigation into the Origins of the Cupisnique Culture. PhD dissertation, Yale University, New Haven, CT.

Olivera Q. (1998) Evidencias arqueológicas del Periodo Formativo en la cuenca baja del río Utcubamba y Chinchipe. Boletín de Arqueología PUCP, 2: 105-112.

Olivera Q. (2014) Arqueología Alto Amazónica. Los Origen de la Civilización en el Perú. Apus Graph Ediciones, Lima.

Onuki Y. (1993) Las actividades ceremoniales tempranas en la cuenca del alto Huallaga y algunos problemas generales. In: Millones L. and Onuki Y. (eds.), El Mundo Ceremonial Andino. Senri Ethnological Studies 37, National Museum of Ethnology, Osaka, pp. 69-96.

Onuki Y. (ed.) (1995) Kuntur Wasi y Cerro Blanco: Dos sitios del Formativo en el norte del Perú. Hokusen-Sha, Tokyo.

Onuki Y. and Inokuchi K. (2011) Gemelos prístinos: El tesoro del templo de Kuntur Wasi. Fondo Editorial del Congreso del Perú/Minera Yanacocha, Lima.

Parker B. (2006) Toward an understanding of borderland processes. American Antiquity, 71: 77-100.

Ramón G. (2005) Periodificación en arqueología peruana: Genealogía y aporía. Bulletin de l'Institut Français d'Études Andines, 34: 5-33.

Renfrew C. and Cherry J. (eds.) (1986) Peer Polity Interaction and Socio-political Change. Cambridge University Press, Cambridge.

Seki Y. (2014a) La diversidad del poder en la sociedad del Período Formativo: Una perspectiva desde la sierra norte. In: Seki Y. (ed.), El centro ceremonial Andino: Nuevas perspectivas para los Períodos Arcaico y Formativo. Senri Ethnological Studies 89, National Museum of Ethnology, Osaka, pp. 175-200.

Seki Y. (ed.) (2014b) El centro ceremonial Andino: Nuevas perspectivas para los Períodos Arcaico y Formativo. Senri Ethnological Studies 89, National Museum of Ethnology, Osaka.

Seki Y., Aleman D., Ordoñez M., and Morales D. (2019) Emergence of power during the Formative Period at the Pacopampa site. In: Burger R., Salazar L., and Seki Y. (eds.), Perspectives on Early Andean Civilization in Peru: Interaction, Authority, and Socioeconomic Organization During the First and Second Millennia BC. Yale University Press, New Haven, CT pp. $107-127$.

Shady R. (2002) Sociedades formativas de Bagua-Jaen y sus relaciones Andinas y Amazonicas. In: Ledergerber-Crespo P. (ed.), Formativo Sudamericano. ABYA-YALA, Quito, pp. 201-211.

Shady R. and Rosas H. (1979) El complejo Bagua y el sistema de establecimiento durante el formativo en la sierra norte del Perú. Ñawpa Pacha, 10: 109-154.

Shimada I., Elera C., and Shimada M. (1982) Excavaciones efectuadas en el centro de Huaca Lucia-Cholope, del Horizonte Temprano, Batan Grande, costa norte del Peru: 1979-1981. Arqueológicas, 19: 109-210.

Shimada M. (1982) Zooarchaeology of Huacaloma: behavioral and cultural implications. In: Terada K. and Onuki Y. (eds.), Excavations at Huacaloma in the Cajamarca Valley, Peru, 1979. University of Tokyo Press, Tokyo, pp. 303-336.

Strong W. and Evans C. (1952) Cultural Stratigraphy in the Virú Valley, Northern Peru: The Formative and Florescent Epochs. Columbia University Press, New York.

Takigami M., Uzawa K., Seki Y., Morales D., and Yoneda M. (2020) Istopic evidence for camelid husbandry during the Formative Period at the Pacopampa site, Peru. Environmental Archaeology, 25(3): 262-278.

Terada K. and Onuki Y. (1982) Excavations at Huacaloma in the Cajamarca Valley, Peru, 1979. University of Tokyo Press, Tokyo.

Terada K. and Onuki Y. (1985) The Formative Period in the Cajamarca Basin: Excavations at Huacaloma and Láyzon, 1982: Report 3 of the Japanese Scientific Expedition to Nuclear America. University of Tokyo Press, Tokyo.

Uzawa K. (2008) La difusión de los camélidos domesticados en el norte del Perú durante el Periodo Formativo. Boletín de Arqueología PUCP, 12: 249-259.

Uzawa K. (2019) A shift in the use of animals in the northern Highlands Formative Period: climate change or social adaptation? In: Burger R., Salazar L., and Seki Y. (eds.), Perspectives on early Andean Civilization in Peru: Interaction, Authority, and Socioeconomic Organization During the First and Second Millennia BC. Yale University Press, New Haven, CT, pp. 97-105.

Uzawa K., Seki Y., and Morales Chocano D. (2021) Ritual consumption and sacrifice of llama (Lama grama) at the Pacopampa site in the Northern Highlands, Peru. Anthropological Science, DOI: 10.1537/ase.2104111 (in press).

Van Gijseghem H. (2006) A frontier perspective on Paracas society and Nasca ethnogenesis. Latin American Antiquity, 17: 419444.

Watanabe S. (2008) Dos monolitos del sitio de Congona, sierra norte del Perú. Boletín de Arqueología PUCP, 12: 53-67.

Willey G. (1971) An Introduction to American Archaeology, Vol. 2, South America. Prentice-Hall, Englewood Cliffs, NJ.

Yamamoto A. (2007) El reconocimiento del valle de Huancabamba, Jaén, Cajamarca, Perú, Arkeos, 2: 1-16.

Yamamoto A. (2010) Ingatambo: Un sitio estratégico de contacto interregional en la zona norte del Perú. Boletín de Arqueología PUCP, 12: 25-51.

Yamamoto A. (2013) Las rutas interregionales en el periodo formativo para el norte del Perú y el sur de Ecuador: una perspectiva desde el sitio Ingatambo, valle de Huancabamba. Arqueología y Sociedad, 25: 9-34. 